\title{
Idealizmo eksportavimas? Baltijos jūros regiono bendradarbiavimo perspektyvos po plètros
}

\begin{abstract}
Vykstant 2004 m. dvigubai NATO ir ES plètrai Baltijos valstybėse pereinamasis procesas po šaltojo karo Baltijos jūros regione eina į pabaigą. Straipsnyje teigiama, kad dẻl to ne tik kyla klausimų, bet gali pasikeisti bendradarbiavimo šiame regione pobūdis. Tvirtinama, kad 1990-aisiais svarbiausias akstinas bendradarbiauti buvo idealizmas ir saugumas, o bendradarbiavimo regione konceptualizacija, kaip identiteto ir savitumo kūrimo projektas, - vienas iš svarbiausių elementų. Pasibaigus pereinamajam procesui, pagrindiniai šio politinio projekto motyvai nebėra tokie svarbūs ir dèl to idealistini regioninio bendradarbiavimo pobūdi keičia labiau pragmatiški, funkcionalūs ir savanaudiški aspektai. Tačiau tvirtinama, kad nors šalių idealizmas, solidarumas ir internacionalizmas mažèja, tačiau visiškai neišnyksta ir vis labiau tampa neatskiriama regiono tarptautinio ịvaizdžio ir identiteto dalimi.
\end{abstract}

\section{Ivadas}

Neseniai ịvykusi dviguba ES ir NATO plètra ị buvusias Rytų bloko valstybes sukèle didelị rezonansą. Kad procesas, nors vizualiai ne toks dramatiškas ir nelydimas euforijos kaip daugiau nei prieš dešimtmetį ivykęs Berlyno sienos griuvimas, užbaigtas, buvo aiškiai suvokiama ir juntama. Iš tiesų, nors ịprasta 1989-1991 m. laikyti šaltojo karo pabaiga, galima tvirtinti, kad šis geopolitinis pasikeitimas iš tikrujų įvyko $2004 \mathrm{~m}$. Tokia buvo kurị laiką vyravusi naujụjų narių nuomoné, ypač 2004-aisiais, kai „grįžimas ị Europą/Vakarus" galiausiai pasiekè kulminaciją. Naujiesiems nariams iškilo svarbus iššn̄kis. Kadangi pastarųjų 10-15 metų politikos varomoji jèga buvo troškimas prisijungti prie Vakarų organizacijų ir grižti „namo“, tai dabar, pasiekus šį tikslą, naujieji nariai susiduria su visiškai nauja problema - kokią politiką vykdyti ir kokių tikslų siekti.

Kalbant apie dvigubą plètrą, kurią derètų suprasti kaip geopolitinį pasikeitimą ir šaltojo karo pabaigą, reiketų pasakyti, kad dabar politikos kaip išimtinai Rytu ir Vakarų santykių apibrèžimą pradès keisti kitokios politikos sampratos. $2001 \mathrm{~m}$. i̇vykiai ir po jų prasidejęs karas su terorizmu taip pat prisidèjo prie Rytų-Vakaru dichotomijos, kaip tam tikro nuolatinio tarptautinès ir Europos politikos scenarijaus, suirimo. Viena vertus, padètis, turint omenyje grèsmes saugumui, iš esmès pasikeitè buvusiems priešams dabar tapus pagrindiniais sajungininkais kovoje su naujo-

"Dr. Christopher S. Browning - Birmingemo (Birmingham) universiteto Politikos mokslu ir Tarptautinių santykių departamento mokslo darbuotojas. Adresas: Department of Political Science and International Studies, University of Birmingham, Edgbaston, Birmingham, B152TT, UK. Tel. +4401214146386, el. paštas - c.s.browning@bham.ac.uk 
mis grèsmėmis. Antra vertus, pačiam Vakarų vieningumui buvo mestas iššūkis atsiradus didelei įtampai transatlantiniame aljanse ir tarp, kaip dabar dažnai sakoma, Naujosios ir Senosios Europos valstybių.

Tvirtinama, kad šis geopolitinis pasikeitimo ir užbaigtumo suvokimas taip pat neabejotinai matomas Baltijos jūros regione. Regiono laimėjimai per pastaraji dešimtmetį buvo dideli. Nepaisant pradinių nuogąstavimų, kad šis regionas gali tapti „Šiaurès Balkanais“, politinis stabilumas ne tik buvo išsaugotas, bet ir palengva tapo savaime suprantamu dalyku. Tai buvo pasiekta taikant daugeli pasitikèjimą didinančių priemonių, kurios labiausiai pasireiškè ryšių ir organizacijų plètra regione. Tačiau ne paskutinị vaidmenị suvaidino aiškus politinis projektas, suteikiantis Baltijos jūros regionui bendrą teigiamą regioninị identitetą ir tam tikra prasme netgi šiek tiek savitumo. Šiuo požiūriu regioninis bendradarbiavimas Baltijos jūros regione atskleide projekto savybes. Tačiau šiandien, panašiai kaip ir kitose šalyse, Baltijos valstybèse, joms tapus ES ir NATO naremis, regiono padètis, tikslas, ateitis ir (ne mažiau!) regioninis bendradarbiavimas nebeatrodo tokie aiškūs dalykai. Straipsnyje nagrinèjama, kaip suprantamas šis proceso „užbaigtumas“ Baltijos jūros regione. Jei pradinis projektas jau užbaigtas, ar bus jis pakeistas ir kas ji pakeis? Ar idealus siekis sukurti bendrą identitetą ir regiono politinį savitumą jau išnyko?

Straipsnį sudaro trys dalys. Pirmiausia nagrinejjami regioninio bendradarbiavimo 1990-aisiais tikslai ir teigiama, kad iš pradžių jis buvo grindžiamas idealizmu ir saugumu. Ypač pabrèžiama, kad proceso „užbaigtumo“ ir tikslo krizè bendradarbiaujant regioniniu lygiu kilo dẻl to, jog, išsprendus daugelị pradinių saugumo uždavinių, regioninio bendradarbiavimo motyvacija sumažejo. Dèl to idealizmą, vyravusị prieš plètrą, pakeite pragmatizmas, kuris susilpnino anksčiau pabréžiamą pasiaukojimą. Tai turejo neigiamų padarinių - idealizuotas politinis projektas siekiant sukurti regioninį savitumą patyrè nesėkmę. Pagaliau straipsnis užbaigiamas pozityvesne gaida, teigiant, esą jaučiama, nors procesas jau užbaigtas ir yra problemų, su kuriomis susidūrẻ identiteto kūrimo projektas, kad regione atsirado bendrų normų, pagrịstų solidarumo ir internacionalizmo idèjomis. Siuo požiūriu formuojasi tarsi Baltijos jūros „regiono eksportui“ idejja. Tam tikru aspektu šis požiūris rodo vidinio regioninio bendradarbiavimo idealizmo, buvusio prieš dvigubą plètrą, išplitimą.

\section{Regioninis bendradarbiavimas po šaltojo karo}

Kaip jau minèta, galima drąsiai teigti, kad didelę dalị regioninio bendradarbiavimo, prasidejjusio Baltijos jūros regione po šaltojo karo, visų pirma skatino idealizmas ir saugumas, kurie, nors ir analitiškai skirtingi, iš tikrujų buvo subtiliai susipynę.

\subsection{Idealizmas}

Šaltojo karo metu regioninis bendradarbiavimas Šiaurès Europoje ir RytųVakarų bei Šiaurès-Pietų kryptimis buvo labai ribotas. Psichologine prasme Baltijos jūra iggavo vandenyno mastą, kuris, atrodo, padidino atstumus ir skiriamąsias ribas. Jūra buvo suvokiama kaip barjeras ir kliūtis bendradarbiauti, o ne kaip erdvè bendradarbiavimui palengvinti. Kaip žinoma, pasibaigus šaltajam karui, visa tai pasikeitè. 
Jūra buvo naujai suvokiama kaip susitelkimo vieta ir bendrumo simbolis ir, užuot buvusi vandenynas, ji pasirode esanti ne tokia jau didelè.

Kartu su šaltojo karo pabaigos euforija visame regione atsirado „baltiškasis jausmas“, suvokiamas kaip proga pamiršti praeities konfliktus naujo bendrumo ir vienybès labui. Šio „baltiškojo jausmo“ idealizmas buvo perteikiamas vartojant daug naujų ir jaudinančių metaforų, kurios padèjo natūraliai priimti vykstančius pasikeitimus ir ėmè vyrauti diskusijose ir kalboje, susijusioje su politikos formavimo klausimais. Tarp jų buvo tokios sąvokos kaip Baltijos Europa, Mare Balticum, Šiaurés regionas ir Ostseeraum ${ }^{l}$.

Panašiai ir ,istorinès“ metaforos, ir tos, kurios buvo susijusios su senosios Hanzos Sajungos prekybos ryšiais, taip pat prisidejo gilinant atsirandanti „, mūsiškumo“ suvokimą, plintantį už Baltijos valstybių ribų. Taigi šaltojo karo padalijimai buvo pateikiami kaip istoriniai epizodai, kuriems pasibaigus regionas galètų susigrą̌inti buvusią gerovę, ramybę ir vienybę. Kaip sakè Suomijos prezidentas Martti Ahtisaari 1999 m., „,nebūtina Žvelgti labai toli ị praeitį per laiko prizmę, ị visur apie Baltijos regioną dèl prekybos ir

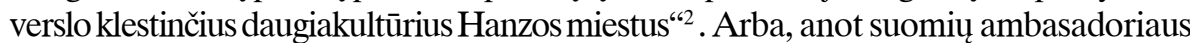
René Nybergo, ryšių atkūrimas su tais, kurie yra kitoje Baltijos jūros pusèje, yra „natūralus“ procesas ir „simbolizuoja grižimą prie normalumo po sẻkmingų pastangų siekiant iveikti nenormalią būseną, taip ilgai neteisingai laikytą ,normalia“(žodžiai paryškinti) ${ }^{3}$.

Tam tikru mastu šis baltiškasis jausmas atsirado gana spontaniškai, neatsiejamai nuo idealizmo, pats tapdamas tarpregioninių ryšiu plètros priežastimi. Kaip pažymėjo Stålvantas, verslininkiškoji dvasia buvo akivaizdi ir skatino pačius piliečius užmegzti tarpusavio ryšius, ypač tarp Šiaurès ir Baltijos valstybių. Tai ypač pasireiškè tuo, kad paplito susigiminiavusių miestų susitarimai, kuriuos igyvendindami Šiaurès partneriai neretai neapsiribodavo vien tik kultūriniu bendradarbiavimu, jog pademonstruotų idealizuotą pasiaukojimo supratimą mažiau turtingų Baltijos pusbrolių labui. Taip susigiminiavusiu miestų susitarimai taip pat tapo būdu humanitarinei ir techninį tobulejimą skatinančiai pagalbai teikti tokiose srityse kaip transportavimas, aplinkos, vandens priežiūra ir energijos tiekimas ${ }^{4}$.

Tačiau tuo pačiu metu, kaip aiškiai parodè Neumannas, akademinis ir užsienio politikos intelektualų elitas taip pat suvaidino svarbų vaidmenį formuojant ir nukreipiant reikiama linkme daug ką, kas buvo pradèta 1990-ujų pradžioje ${ }^{5}$. Šie „regiono formuotojai“, kaip Neumannas teigia, parengè aiškų politinị regiono projektą, kuriame atsispindèjo istorijos ir geografijos žinios bei vizija, kad paremtų įvai-

${ }^{1}$ Christiansen T. \& and Joenniemi P., „Politics on the Edge: On the Restructuring of Borders in the North of Europe“, Eskelinen H., Liikanen I. \& Oksa J., eds., Curtains of Iron and Gold: Reconstructing Borders and Scales of Interaction, Aldershot: Ashgate, 1999, p. 92.

${ }^{2}$ Ahtissari M. kalba, pasakyta Karelijos vasaros festivalyje, Vaasa, 1999 m. birželio 19 d., žr.: http:/ /www.tpk.fi/puheet-1999/p990619.karen.html

${ }^{3}$ Nyberg R., „The Dynamic Baltic Sea Regio: What belongs Together is Now Growing Together“, kalba, pasakyta Greifswalde, 2000 m. kovo 30 d., žr.: http://virtual.finland.fi/news/showarticle.

${ }^{4}$ Stålvant C. E., ,Trans-national Forces and the Role of Local Actors“, Browning C., ed., Remaking Europe in the Margins: Northern Europe after the Enlargements, Aldershot: Ashgate, bus išspausdinta 2005 m. Taip pat žr.: Bergman A., „Nordic Integration Assistance: The Case of the Baltic States“, pranešimas, skaitytas Glasgo universiteto konferencijoje „The Baltic States: New or Old?“, $2004 \mathrm{~m}$. sausio $22-23 \mathrm{~d}$.

${ }^{5}$ Neumann I. B., „A Region-Building Approach to Northern Europe“, Review of International Studies 20, 1994, p. 53-74. 
rius regioninio bendradarbiavimo projektus, kurių tikslas buvo padèti puoselèti aiškų bendro identiteto suvokimą visame Baltijos jūros regione. Be to, siekiant oficialiai ịtvirtinti ši bendradarbiavimą tokiose organizacijose kaip Baltijos jūros valstybių taryba (BJVT - 1992) ir Barenco Euro-Arkties taryba (BEAT - 1993), buvo taip pat numatoma skatinti politinị regiono savitumą.

Tačiau buvo kitas, dar būdingesnis, to idealizmo, kuriuo grindžiamas regioninis bendradarbiavimas po šaltojo karo, Šiaurès elementas. Kaip pažymėjo Wæveris, tuoj pat po šaltojo karo iškilo kai kurie su Šiaurès bendradarbiavimu susiję klausimai, kur „senoji“ centralizuota Šiaure buvo nepalankiai lyginama su šio Europos projekto dinamiškumu, kas tapo visiškai akivaizdu rengiantis Mastrichto sutarčiai ${ }^{6}$. Nors per visą šaltajį karą Šiaurès valstybės puoselëjo pažangų įvaizdi, pagrịstą solidarumu su Trečiuoju pasauliu, internacionalizmu, gamtosauga ir egalitariniu savo visuomenių gerovès pobūdžiu ${ }^{7}$, po Berlyno sienos griuvimo Šiaurès modelis nebeatrode toks ypatingas. Iškilo klausimu, ką reiškia būti Šiaurès valstybe naujajame pasaulyje ir kokị tarptautinị vaidmeni Š Siaurès šalys galètų suvaidinti.

Po šaltojo karo persiorientuodamos Śiaurès valstybės faktiškai iš naujo patvirtino savo tarptautinị mandatą ir toliau skirdamos dèmesị solidarumui su tais, kuriems mažiau pasisekẻ. Tai pasireiške įvairiomis formomis. Pavyzdžiui, stipriu noru išlaikyti tarpininko vaidmeni globalinių konfliktų metu (pvz., aktyvus Norvegijos dalyvavimas Artimujų Rytų taikos procese). Tai taip pat matoma ir stebint, kad Suomija ir Švedija paremè Petersbergo uždavinius, kaip sudedamają 1997 m. ES Amsterdamo sutarties dalị. Tai garantavo joms galimybę dalyvauti ES taikos palaikymo operacijose, nors jos, kaip neprisijungusios šalys, nebuvo Vakarų Europos Sajungos (VES) narès. Žinoma, solidarumas taip pat matomas ir stebint, kad Šiaurès šalys išlieka pirmosios skiriant bendrojo vidaus produkto procentinę dali paramai ${ }^{8}$.

Tačiau aiškiausiai Šiaurès internacionalizmas buvo nukreiptas i arčiausiai esantị Baltijos jūros regioną, ypač siekiant padèti Baltijos valstybėms pereinamojo proceso laikotarpiu, tuo pat metu bandant užkirsti kelią atsirandančiam normatyviniam ir ekonominiam sajungos su Rusija skilimui. Akivaizdu, kad šiame kontekste ankstesni Šiaurės šalių pranašumo elementai išliko, ypač siekiant platinti Šiaurès standartus tarp savo pietinių kaimynų. Kaip pažymi Archeris, pasinaudodamos šaltojo karo metu palankia savo identiteto raiška, kurios Šiaurès šalys laikèsi su misionierišku atsidavimu, jos suvokẻ Šiaurès vertybių, ypač jų saugumo, atkūrimą kaip galutinị tikslą ${ }^{9}$. Laikydamos Baltijos valstybes naujos Šiaurès šalių misijos veiklos rajonu, siekdamos ịkvejpti baltams atsakomybès jausmą tvarkant tarptautinius reikalus, Šiaurès valstybès sukūrẻ bendravimo sistemą, kurioje jos autoritetingai teike žinias baltams - studentams. Todèl nenuostabu, kad 1998 m. tuometė užsienio reikalų ministrè Tarja Halonen jaute galinti pavaizduoti Suomiją kaip Estijos „krikštamo-

\footnotetext{
${ }^{6}$ Wæver O., „Nordic Nostalgia: Northern Europe after the Cold War“, International Affairs 68 (1), 1992.

${ }^{7}$ Mouritzen H., ,The Nordic Model as a Foreign Policy Instrument: Its Rise and Fall“, Journal of Peace Research 32 (1), 1995, p. 10-11.

${ }^{8}$ Bergman A., „Post-Cold War Shifts in Swedish and Finnish Security Policies: The Compatibility of Non-Alignment and Participation in EU Led Conflict Prevention“, pranešimas skaitytas Europos politikos tyrimų konsorciumo konferencijoje, Upsalos universitete, $2004 \mathrm{~m}$. balandžio 13-18 d.

${ }_{9}^{9}$ Archer C., „Nordic Swans and Baltic Cygnets“, Cooperation and Conflict 34 (1), 1999, p. 62.
} 
tę" dèl Estijos ir Rusijos santykių plètros ${ }^{10}$. Dar daugiau - kai Baltijos valstybėms reikèjo suteikti gynybos paramą, Siaurès šalys aktyviai rẻmė Baltijos taikos palaikymo bataliono kūrimo procesą, ir tai iš dalies paaiškinama jų troškimu perteikti savo internacionalines vertybes Baltijos kaimynams ${ }^{11}$.

\subsection{Saugumas}

Pasibaigus šaltajam karui, saugumo motyvai buvo tokie pat svarbūs kaip ir ịvairios idealizmo apraiškos, pasireiškiančios Baltijos jūros valstybių regioniniame bendradarbiavime. Iš tikrujų regiono saugumas ir bendradarbiavimas tapo taip glaudžiai susiję, kad pasidare sunku galvoti apie juos atskirai. Tačiau saugumas, kaip bendradarbiavimo Baltijos jūros regione varomoji jèga, turi dvi skirtingas sudedamąsias dalis, tad bendradarbiavimą skatina tiek realistinis, tiek liberalusis saugumo diskursai. Nors paprastai papildančios viena kitą, Baltijos jūros regiono atveju šios dalys gerokai skiriasi, ypač kai kuriais klausimais - kas yra konkretus saugumo objektas, kaip nustatomas grèsmès ir bendradarbiavimo, kuris tampa galimu, pobūdis? ${ }^{12}$

Pavyzdžiui, realistinio požiūrio ị tarptautinę politiką šalininkai linkę pabrežti problemas, susijusias su tvirtu kariniu saugumu, ir pateikia tarptautinę sistemą kaip anarchinę Hobso visuomenę, kur visi yra prieš visus. Vyraujant tokiam pesimistiniam ir konfliktų komplikuojamam požiūriui ị tarptautinę politiką, realistinis saugumo suvokimas paprastai siejamas su specifinemis nuostatomis ir tarptautinio bendradarbiavimo apribojimais. Bendradarbiavimas tarp valstybių paprastai suprantamas kaip sąjungos sukūrimas ir pusiausvyros (arba naujų šalininkų pritraukimo) išlaikymas santykiuose su kitomis valstybėmis, kurios kelia grèsmę saugumui ir nepriklausomybei ${ }^{13}$. Todèl,žvelgiant iš realistinių pozicijų, šalys laikomos konkrečiu saugumo objektu (kas turi būti saugojama ir ginama). Taip pat suprantama, kad pagrindines grèsmes valstybei kelia kitos valstybės. Dèl to regioninis bendradarbiavimas grindžiamas atmetimo ir atskyrimo logika ir lieka ribotas, kadangi valstybès sudaro sajungas su kai kuriomis valstybẻmis dẻl suvokiamų kitų valstybių agresyvių ketinimų.

Po šaltojo karo bendradarbiavimas, skatinamas realistinių saugumo diskursų, buvo aiškiausiai matomas Baltijos valstybėse ir Lenkijoje, kurioms įsitraukimas ị bendradarbiavimą su Vakarų ir Šiaurès kaimynais buvo svarbiausia strategija siekiant ištrūkti iš Rusijos įtakos sferos ir igyti Vakarų saugumo garantijas ${ }^{14}$. Taigi, tvirtinama, kad nors pastaraisiais metais Baltijos valstybès pasirinko bendro saugumo kalbą ir pareiškè norą tapti NATO naremis pasinaudodamos "naujosios NATO“ sąvoka, tebèra aišku, kad šie siekiai slepia didelį nora gauti tvirtas karinio saugumo garantijas dèl Rusijos grèsmès ${ }^{15}$. Panašiai ir narystès ES ir NATO svarbos pabrèži-

\footnotetext{
${ }^{10}$ Kansan Uutiset , 1998 m. gruodžio 16 d., citata http://virtual.finland.fi/news/.

${ }^{11}$ Bergman (8 išnaša).

${ }^{12}$ Platesnis šio argumento paaiškinimas: Browning C. \& Joenniemi P., „Regionality Beyond Security? The Baltic Sea Region after Enlargement", Cooperation and Conflict 39 (3), 2004, p. 233-253. ${ }^{13}$ Walt S., The Origins of Alliances, Ithaca and London: Cornell University Press, 1987.

${ }^{14}$ Archer C. \& Jones C., ,The Security Policies and Concepts of the Baltic States - Learning from their Nordic Neighbours?", Knudsen O. F., ed., Stability and Security in the Baltic Sea Region: Russian, Nordic and European Aspects, London: Frank Cass, 1999, p. 168-169.

${ }^{15}$ Ten pat, p. 171.
} 
mas Baltijos valstybių ir Lenkijos (kartu ir Suomijos) „grị̌imo ị Europą“ diskurse konstruojant jų identitetą po šaltojo karo, atskleidè ir tam tikrą realistinị saugumo elementą. Nors šiuose diskursuose narystè yra prilyginama jų trokštamo identiteto tarptautiniam pripažinimui, jis prasmingas tik tiek, kiek „Vakarai“ priešpriešinami neigiamai vaizduojamiems „,Rusijos Rytams“, kuriuos jos palieka ${ }^{16}$. Kitaip tariant, šiame kontekste integracija ir regioninis bendradarbiavimas buvo suprantami kaip valstybės saugumą sustiprinantys veiksniai prieš kitą, suvokiamą kaip potencialią grèsmę, valstybę (Rusiją).

Tačiau, priešingai atskirtiniams realistiniu saugumu pagrịsto regioninio bendradarbiavimo elementams, liberali saugumo samprata taip pat buvo svarbi ir skatino regioninị bendradarbiavimą truputị kitaip. Skirtingai nuo realistinès saugumo sampratos, kuri pabrěžia valstybės suverenitetą ir karinius klausimus, liberalistinis saugumo diskursas apima daug platesnę sritį. Liberalizmo diskursai akcentuoja „lengvojo“ saugumo problemas, tokias kaip pasaulinis atšilimas, aplinkosaugos, ekonomikos efektyvumo ir visuomenès sveikatos problemos, migracija ir gerove apskritai. Kitaip tariant, karinę dimensiją papildo aplinkos, visuomenès ir ekonomikos elementai. Dèl to, kad liberali samprata akcentuoja „lengvojo“ saugumo problemas, valstybė gali neišlikti kaip „natūralus“ saugumo objektas. Taikant liberalias saugumo nuostatas, valstybès paprastai apibūdinamos kaip priemonės, naudojamos kitų saugumo objektų reikmėms paremti, nesvarbu, ar tai būtų paskiri žmonès, ar visuomenès grupès, ar netgi aplinka ${ }^{17}$.

Svarbu ir tai, kad „lengvojo“ saugumo grèsmés paprastai suprantamos kaip transnacionalinès, todèl jokia valstybè negali viena su jomis susidoroti. „Lengvojo“ saugumo grèsmès paprastai yra tarpvalstybinio, regioninio ir net globalinio masto, todèl, norint jas ịveikti, reikia ịvairioms valstybėms ir organizacijoms bendradarbiauti. Reikètų pasakyti, kad, skirtingai nuo realistinio saugumo sampratos, „lengvojo " saugumo grésmés yra ne kitos valstybės, bet tokie dalykai kaip užterštumas, tarptautinis nusikalstamumas ar užkrečiamosios ligos. Nors tarp nagrinëjančiujų saugumo problemas daug diskutuojama, ar plečiant saugumo darbotvarkę verta ịtraukti tokius klausimus ${ }^{18}$, Wæverio, kuris pateikia socialines, ekonomines ir aplinkosaugos problemas kaip ,saugumo“ klausimus, įsitikinimu, tai, atrodo, svarbu skatinant

${ }^{16}$ Tokios išskirtinès sampratos pavyzdžiu ieškokite: Browning C., „Coming Home or Moving Home? 'Westernizing' Narratives in Finnish Foreign Policy and the Reinterpretation of Post Identities", Cooperation and Conflict 37 (1), 2002, p. 47-72; Fieldman G., „Shifting the Perspective on Identity discourse in Estonia“, Journal of Baltic Studies 31 (4), 2000, p. 415-416; Jæger O., Securitising Russia: Discursive Practices of the Baltic States, Copenhagen: Copenhagen Peace Research Institute, 1997 (Working paper No 10); Kuus M., „From threats to risks: The Reconfiguration of Security Debates in the Context of regional Co-operation“, Kasekamp A., ed., The Estonian Foreign Policy Yearbook 2003, Tallin: The Estonian Foreign Policy Institute, 2003, p. 14-17; Lauristin M., Vihalemm P., Rosengren K. \& Weibull L., ed., Return to the Western World: Cultural and Political Perspectives on the Estonian Post-Communist Transition, Tartu: Tartu University Press, 1997.

${ }^{17}$ Apie čia minimas diskusijas plačiau: Terriff T., Croft S., James L. \& Morgan P., Security Studies Today, Gateshead: Polity, 1999, 6 ir 7 skyriai; Buzan B., Wæver O. \& de Wilde J., Security: A New Framework for Analysis, London: Lynne Rienner, 1998; Booth K., „Security and Emancipation“, Review of International Studies 17 (4), 1991, p. 313-326.

${ }_{18}$ Žr., pvz., Møller B., The Concept of Security: The Pros and Cons of Expansion and Contraction, Copenhagen: Copenhagen Peace Research Institute, 2000 (Working Paper No 26); Deudney D., "The Case Against Linking Environmental Degradation and National Security“, Millennium 19, 1990, p. 461-476. 
veikti. Pateikiant kokį nors dalyką kaip saugumo problemą, t. y., jei vartosime Wæverio terminą, $\mathrm{ji}$, ,saugumizuojant“, jis gali tapti neatidèliotinas, labai svarbus ir patraukti dėmesį, taip skatindamas žmones veikti ${ }^{19}$.

Baltijos jūros regione „lengvujų“" problemų „saugumizacija“ buvo svarbi priežastis atsisakyti ịprastinių teritorinių apribojimų ir skatinti regioninị bendradarbiavimą. Tačiau, palyginti su realistine nuostata, esminis skirtumas yra tas, kad nors regioninị bendradarbiavimą tebelemia grèsmés saugumui, jis jau nebėra grindžiamas Rusijos atmetimu griežtai atsiribojant. Tačiau „saugumas“ tapo argumentu, vienijančiu visus regione. Priešingai realistiniam „,bendradarbiavimui atmetant“", tai yra „bendradarbiavimas ịtraukiant". Tokios liberalios nuostatos aiškiai matomos, pavyzdžiui, Šiaurès dimensijos iniciatyvoje, BJVT ir BEAT darbotvarkèse. Tačiau kalbant apie Šiaurès dimensiją, būtina ypač pabrežzi tai, kad ji aiškiai traktuoja Rusiją kaip lygiavertę partnerę, turinčią teisę pareikšti savo nuomonę formuojant ir ịgyvendinant politiką, netgi jei faktiškai tokia lygybès retorika ne visada igyvendinama ${ }^{20}$. Apskritai kaip tik Šiaurès šalys ir Vokietija buvo pirmosios, propaguojančios liberalią saugumo sampratą, kaip būdą regioniniam bendradarbiavimui Baltijos jūros regione skatinti, kai būtent Šiaurès šalys suprato savo užduotị po šaltojo karo „eksportuoti“ “ $i$ Baltijos valstybes ir Rusiją tokias sąvokas kaip visapusiškas, pilietinis ir bendradarbiavimo dvasia pagristas saugumas ${ }^{21}$.

Ir pagaliau, nors liberaliuoju saugumu grindžiamas bendradarbiavimas skiriasi nuo realistinio bendradarbiavimo, Baltijos jūros regione jie abu yra glaudžiai susiję. Kad būtų priimta liberaliomis nuostatomis pagrịsta darbotvarkè, reikejjo ịtikinti pagrindines šalis veikejjas, jog laikantis tokios pozicijos galima teigiamai paveikti ir realistinę darbotvarkę. Taigi „lengvujų “ saugumo klausimų akcentavimas buvo suprantamas kaip tarpininkavimo būdas sprendžiant tarpvalstybinių santykiu problemas ir ypač kuriant pasitikejjimą tarp Rusijos ir Baltijos valstybių bei Lenkijos per abiem pusėms naudingus bendradarbiavimo projektus. Kitaip tariant, „lengvuju“ “ problemų ,saugumizavimas“ tapo būdu atmetimo politikai regione ịveikti ir galimybe pareikšti, kad mes visi išvien. Dar daugiau - ši idèja išeiti už tradicinių realistinès politikos svarstymų ir ịveikti atmetimo reakciją regione taip pat aiškiai atsiliepia tam idealizmui, kuris akivaizdus minètame regione. Igyvendinant Siaurès dimensiją, BEAT ir BJVT stengiamasi, kad nepasikartotu praeities padalijimai ir konfliktai. Todèl, kalbant apie Rusiją, nebemanoma, kad ši grèsmė yra Rusijos kaip revanšistinès valstybès atkūrimas, bet tai, kad ji gali išsiskaidyti, tapti chaotiška ir sujaukta valstybe, kurioje bus sunku kontroliuoti aplinkosaugos problemas, organizuotą nusikalstamumą ir migracijos srautus ${ }^{22}$.

\footnotetext{
${ }^{19}$ Wæver O., „Securitization and Desecuritization“ in Lipshultz R., ed., On Security, New York: Columbia University Press, 1995, p. 46-86.

${ }^{20}$ Browning C., „The Region-Building Approach Revisited: The Continued Othering of Russia in Discourses of Region-Building in the European North“, Geopolitics 8 (1), 2003, p. 45-71.

${ }^{21}$ Archer C. \& Jones C., ,The Security Policies and Concepts of the Baltic States - Learning from their Nordic Neighbours?", Knudsen O. F., ed., Stability and Security in the Baltic Sea Region: Russian, Nordic and European Aspects, London: Frank Cass, 1999, p. 173-175.

${ }^{22}$ Herolf G., „Attitudes and Policies of Sweden in the Baltic Sea Region“ in Hubel H., ed., EU

Enlargement and Beyond: The Baltic States and Russia, Berlin: Berlin Verlag, 2002, p. 235.
} 


\section{Plètros iššūkis}

Jeigu regioninis bendradarbiavimas Baltijos jūros regione nuo šaltojo karo pabaigos buvo labiausiai skatinamas idealizmo ir saugumo motyvų, tai šiame straipsnyje teigiama, jog neaišku, ar po dvigubos NATO ir ES plètros ị Baltijos valstybes ir Lenkiją regioninis bendradarbiavimas ir toliau vyks taip pat ir su tokiu pat entuziazmu. Čia pagrindine problema susijusi su tuo faktu, kad po dvigubos plètros svarbiausias šio regiono saugumo klausimas buvo išspręstas, t.y. išsipilde Baltijos valstybiu troškimas įstoti i Vakarų saugumo organizacijas. Dar daugiau - jis ne tik kad buvo išspręstas, bet buvo išspręstas palyginti draugiškai Rusijai tai pripažinus, jei ne atvirai pritarus. Dèl to dabar gerokai mažiau yra priežasčių suvokti Baltijos jūros regioną kaip potencialų neramumų rajoną.

Dar daugiau - vykstant karui su terorizmu Rusija vis labiau laikoma pagrindine transatlantinès saugumo bendruomenės partnere. Iš tikrųjų po Rugsëjo 11-osios atsirado nauja saugumo darbotvarké, kurioje pagrindiniai regiono tvirto saugumo klausimai jau nebėra taip teritoriškai fiksuoti, o Rusijos santykių su Baltijos valstybėmis tema - dominuojanti. Svarbesnès tapo globalinés kovos su terorizmu ir masinio naikinimo ginklų platinimu problemos, kur saugumas nebeįsivaizduojamas tiktai regioniniame kontekste. Atsirado globalinis mastas, be abejo, sumenkinantis saugumo motyvų skatinamą bendradarbiavimą, kuris anksčiau buvo ypač svarbus regionui.

Tai svarbu, kadangi regioninis bendradarbiavimas Baltijos jūros regione turi aiškius projekto bruožus ir dažniausiai yra suprantamas kaip priemonė kuriant saugumą ir stabilizuojant regioną pereinamojo proceso po šaltojo karo metu. Žinoma, šis pereinamasis laikotarpis ir stabilizacija jau baigèsi ir panašu, kad ji pakeis laikotarpis, kai bus akcentuojama normalizacija ir kur dauguma tradicinių samprotavimų apie realistinị saugumą bus išbraukti iš darbotvarkès. Turint galvoje tokią proceso „užbaigtumo" prasmę, kyla klausimas, kas dabar skatins regionini bendradarbiavimą, kai pagrindinès realistinio saugumo problemos (kurios taip pat buvo daugelio liberaliu paskatų nulemto bendradarbiavimo regione pagrindas) tapo nebe tokios akivaizdžios.

Siekiant pateikti išsamesnị paaiškinimą, čia galima iškelti mažiausiai dvi problemas. Pirmoji ta, jog neteigiama, kad ịprasti regioniniai kontaktai nutrūks, kadangi taip nebus. Klausimas daugiau apie tai, ar regioninis bendradarbiavimas kaip politinis identiteto kūrimo ir mėginimo suteikti regionui aiškų savitumą projektas turès ateitị tame kontekste, kuriame tokiais siekiais paremti pradiniai tikslai jau yra pasiekti. Tai siejasi su kita, t.y. motyvacijos, problema. Kaip yra pažymėjęs Stålvantas, jeigu einame iš stabilizacijos ị normalizacijos laikotarpị, tuomet gali būti, kad pereiname ir iš idealizmo laikotarpio ị laikotarpị, kai vyrauja pragmatizmas ir savanaudiškumas. Jo žodžiais tariant, atrodo, jog regioninį bendradarbiavimą skatinantys projektai turètų pasikeisti Baltijos jūros regionui pereinant ị normalizacijos laikotarpị. Vietoj anksčiau skatinusių veikti pasiaukojimo ir solidarumo motyvų vis labiau ịsigalès materialistiniai išskaičiavimai. Dèl to, anot jo, nutrūks kai kurie tarpregioniniai ryšiai ${ }^{23}$.

Yra akivaizdžių faktų, rodančiu, jog kai kurie ambicingi ir idealistiniai Baltijos jūros regiono bendradarbiavimo projektai pradeda strigti. Pavyzdžiui, Šiaurès šalys pradèjo ma-

${ }^{23}$ Stålvant, (4 išnaša). 
žinti investicijas ị Baltijos jūros regiono bendradarbiavimo projektus. Bene ryškiausias pavyzdys būtų gerai žinomo Švedijos Baltijos jūros milijardinio fondo projekto, pradèto 1996 metais, siaurinimas, kas patvirtina Stålvanto nuomonę, kad ateityje pasiaukojimo idealai bus ne tokie ryškūs ${ }^{24}$. Taip pat reikia paminèti, kad BJVT panaikino savo buvusio komisaro demokratijos plètros reikalams postą ir dabar retina aukščiausiojo lygio susitikimus. Vienas paaiškinimu - kad pasibaigus pereinamajam laikotarpiui ir kuriantis naujai Europos tvarkai darosi aišku, jog Baltijos jūros valstybès jau nebelaiko BJVT tokiu svarbiu instrumentu ${ }^{25}$. Arba, anot Atiso Lejinšo, BJVT prarado savo pradinę reikšmę ir akivaizdu, kad jai reikalinga nauja misija ${ }^{25}$. Tačiau ar ji ją gaus, yra kitas klausimas.

Dar vienas svarbus pavyzdys. Mažeja Amerikos įsipareigojimai šiam regionui ir jo finansavimas per Sustiprinta partnerystę Šiaurés Europoje (e-PINE). Pavyzdžiui, 2003 metais pertvarkant Šiaurès Europos iniciatyvą (ŠEI) į e-PINE, su šia politika susiję JAV pareigūnai buvo susirūpinę, kad šios iniciatyvos nebūtų visiškai atsisakyta remiantis tuo, kad Baltijos valstybèms ịstojus į NATO nebėra jokios būtinybės tęsti tokią bendradarbiavimą skatinančią regioninę politiką ${ }^{27}$. Nors ŠEI ir buvo performuota, jai skirti ištekliai yra gerokai apriboti ${ }^{28}$.

Nors pereinamasis laikotarpis eina ị pabaigą, galima išskirti ir keletą kitų su tuo glaudžiai susijusių priežasčių, kurios galètų paaiškinti akivaizdų regioninio bendradarbiavimo, kaip identiteto ir savitumo kūrimo politinio projekto, susilpnèjimą. Galbūt pirmiausia reikètų pažymèti tai, kas galètų būti ịvardyta kaip marginalizacijos baimé, kuri jaučiama visame regione. Reikia pasakyti, kad 1990-ųju pradžioje ir viduryje Baltijos valstybès nebuvo taip tvirtai ịitikinusios Baltijos jūros regiono bendradarbiavimo nauda, būgštaudamos, kad tai nebūtų narystès ES ir NATO pakaitalas. Pavyzdžiui, tai buvo labai akivaizdu atsiradus pirmiesiems Baltijos šalių nuogąstavimams, susijusiems su 1998 m. JAV ir Baltijos valstybių Partnerystès Chartija, kurią kai kas Baltijos valstybėse suprato kaip būdą atidèti NATO plètros klausimą ir palikti Baltijos valstybes pilkojoje zonoje tarp NATO ir Rusijos ${ }^{29}$. Žinoma, vẻliau imta suvokti, kad būtent regioninis bendradarbiavimas yra tarsi pasirengimas būsi-

${ }^{24}$ Žr. Švedijos užsienio reikalų ministerijos interneto puslapi http://www.utrikes.regeringen.se/inenglish/policy/balticbillion/

${ }_{25}$ Dauchert H., „No Future for the Council of Baltic Sea States? The Implications of Baltic State's EU and NATO Membership for the CBSS“, dokumentas pateiktas BaltSeaNet konferencijoje Taline, $2004 \mathrm{~m}$. vasario 5-8 d.

${ }^{26}$ Lejins A., „The EU and NATO on the Shore of Baltic Sea“, NATO Enlargement Daily Brief, $2003 \mathrm{~m}$. gruodžio 23 d. pirmą kartą šis straipsnis pasirode Latvijos laikraštyje „Diena“, 2003 m. gruodžio $20 \mathrm{~d}$.

${ }_{27}$ Žr.: Šiaurès Europos iniciatyvos konferencija-seminaras, 2003 m. sausio 17-18 d., Rutgeris Universitetas, New Bruswick, New Jersey. Žr.: http://www.ciaonet.org/; Larrabee F. S., „The Baltic States and NATO Membership", duomenys pateikti Jungtinių Valstijų Senato Užsienio ryšiu komitetui 2003 m. balandžio 3 d. Žr.: http://www.rand.org.

${ }^{28}$ Pvz., atkreipkite dèmesį, kad šioje ižanginèje kalboje, susijusioje su e-PINE, neužsimenama apie naują finansavimą. Conley H., „Building on Success: The Enhanced Partnership in Northern Europe“; pastabos pateiktos Aukštujų tarptautinių studijų mokykloje, Vašingtonas, Kolumbijos apygarda, 2003 m. spalio 15 d. Žr.: http://www.state.gov/p/eur/rls/rm/2003/25286pf.ftm (Perkelta 2003 11 27).

${ }^{29}$ van Ham P., „US Policy Toward the Baltic States: An Ambiguous Commitment“ in Jopp M. \& Arrnswald S., ed., The European Union and Baltic States: Visions, Interests and Strategies for the Baltic Sea Region, Helsinki: Ulkopoliittinen instituutti \& Institut für Europäische Politic, p. 223-24. 
majai narystei ES bei NATO, simbolinè parama šį̣ šalių vakarietiškajam identitetui, ko šiandien jau nebereikia. Tačiau jeigu regioninis bendradarbiavimas buvo suprantamas kaip būdas pasiekti pripažinimą ir ištrūkti iš to, kas buvo suvokiama kaip kritiška padètis, tada kam ateityje Baltijos valstybèms bus reikalingos pagrindinès regioninès institucijos? Kyla klausimas, ar ateityje jos norès teikti tiesioginę pirmenybę ES ir NATO, o ne regioninio lygmens svarbai, kas sustiprintų tą pačią marginalinę padèti, iš kurios jos taip norejo ištrūkti.

Panašių būgštavimų dèl pavojaus būti marginalizuotiems ir likti Europos pakraščiuose galima pastebėti ir Šiaurès šalyse. Ir jie vis dažniau atsiduria tarp svarbiausių klausimų diskutuojant apie ES ir NATO. Cia būtina pasakyti, kad valstybės turi rodyti vis didesni aktyvumą ten, kur yra priimami svarbiausi sprendimai. Teisinga ar ne, tačiau atrodo, jog tai vis labiau vyksta ne Baltijos jūros regione, o Briuselyje.

Kita priežastis, kuri galètų paaiškinti, dėl ko mažèja regioninis bendradarbiavimas, gali būti ta, jog nors ir buvo tikslų sukurti bendrą identitetą ir išsaugoti savitumą, paaiškejjo, kad pasibaigus pereinamajam procesui regione nebėa bendrų interesų. Nors tam tikros regioninės problemos, kaip transportavimas, prekyba, užterštumas ir t. t., žinoma, ir toliau išlieka ir bus sprendžiamos regioniniu lygiu, tačiau (bent jau ES politikos kontekste) nebeaišku, kur ieškoti bendrų interesų ir pozicijų. Tačiau reikia pažymėti, kad, i̇ykus ES plètrai, Sajungoje buvo mėginama skatinti Šiaurès ir Baltijos šalių veiklos koordinavimą. Atsirado modelis , $3+3$ “, pagal kurị trys Baltijos valstybių ministrai pirmininkai ir trys Šiaurès šaliu ES narių ministrai pirmininkai dukart per metus susitinka prieš prasidedant Europos Tarybos posèdžiams. Pirmasis toks susitikimas ívyko $2003 \mathrm{~m}$. birželio mèn. Stokholme ${ }^{30}$. Lietuva taip pat parodè iniciatyvą sukurti tai, kas vèliau buvo pavadinta Šiaurès ir Baltijos aštuntuku (NB-8), kur Šiaurès ir Baltijos šalių parlamentų vadovai (tačiau, pažymètina, be Lenkijos ir Vokietijos) rengia susitikimus, siekdami suderinti savo pozicijas, kurių tikslas yra sustiprinti šios grupès parlamentarų vaidmenį besiplečiančioje ES. Be to, Lietuva pasiūle Baltijos grupę sudaryti Europos Parlamente ${ }^{31}$.

Tačiau, nepaisant šių žingsnių, nėra aišku, ar bus taip paprasta išreikšti bendrus interesus ir pozicijas. Kalbant apie Šiaurés valstybes, kartais pažymima, kad buvo baiminamasi, jog po 1995 metais ịvykusios pletros jos gali sudaryti Šiaurès bloką Europos Sajungoje, tačiau faktiškai įvairios Siaurès šalys dažnai rasdavo daugiau bendrumų su kitomis ES naremis negu viena su kita. Be to, tai, kad Šiaurès ir Baltijos valstybès turi gana skirtingus socialinio ir ekonominio vystymosi modelius, taip pat gali reikšti, jog regioniniai ryšiai gali būti ne tokie stiprūs kaip ryšiai su kitomis ES valstybėmis. Kaip yra pabrěžusi Ojanen, netgi turint bendrus tikslus, gali atsitikti taip, kad dažnai bus nesutariama, kokia politika yra teisinga siekiant šių tikslų. Taip pat nereikètų pamiršti, kad išsiplètusioje ES Šiaurès ir Baltijos valstybės bus ne tik potencialūs partneriai, bet ir potencialūs konkurentai, ypač tuomet, kai bus daroma įtaka Europos Sajungos politikai Rusijos atžvilgiu ${ }^{32}$. Ir pagaliau, kad nėra bendrų pozicijų, taip pat buvo akivaizdu pastaruoju metu vykusiuose ginčuose dèl

\footnotetext{
${ }^{30}$ Lejins, (26 išnaša).

${ }^{31}$ Miniotaite G., ,Lithuania's New Neighbors policy in the Framework of the EU's Wider EuropeNeighbourhood Initiative“, Vilnius, 2004 m. kovo mèn.

${ }^{32}$ Ojanen H., „Enlargement: A Permanent Threat for the EU, and a Policy Problem for Finland?“ Northern Dimensions Yearbook 2001, Helsinki: Finish Institute for International Affairs, 2001, p. 29.
} 
transatlantinių santykių, susijusių su karu Irake. Regionas gana aiškiai pasidalijo ị Naujosios ir Senosios Europos stovyklas, kur Danija, Lenkija ir Baltijos valstybès aktyviai rèmė JAV, o Suomija, Vokietija, Norvegija ir Švedija JAV veiksmus ir politiką vertino gana santūriai.

Kitaip sakant, atrodo, jog pasibaigus pereinamajam procesui saugumo problemos ir idealizmas, anksčiau sieję visą regioną ir vertę kalbèti apie regioninį bendradarbiavimą kaip apie identiteto formavimo ir savitumo kūrimo procesą, pradejo strigti. Todèl lieka neaišku, ar regioninis bendradarbiavimas, kaip projektų igyvendinimo procesas, turi dideles perspektyvas Šiaurès šalyse. Panašu, kad ims vyrauti ne siekis būti „identiteto regionu“, o daug funkcionalesni, pragmatiškesni ir savanaudiškesni elementai. Nors kai kas gali apgailestauti dèl tokios ịvykių raidos ir siekti atnaujinti identiteto projektą, taip pat reikètų pažymèti, kad būtent ši pletra ir parodé, jog 1990-ujju regioninio bendradarbiavimo ir regiono kūrimo projektas buvo labai sẻkmingas.

\section{Išvados. Regiono kūrimas eksportui}

Apibendrinant reikia pasakyti, jog nenorima teigti, kad solidarumo ir idealizmo sąvokos paprasčiausiai išnyko. Atrodo, kad pasibaigus pereinamajam procesui dėmesys telkiamas įidealizmą ir solidarumą už regiono ribu. Regis, tam tikra prasme Šiaurès šaliu internacionalinės pažangiosios vertybės buvo paskleistos Baltijos valstybėse. Regiono formavimo Baltijos jūros regione patirtis ir ypač Baltijos valstybių patyrimas pereinamuoju laikotarpiu vis labiau suprantami kaip kažkas, ką galima būtų eksportuoti i kitus kaimyninius regionus. Viena vertus, tai galbūt atspindi troškimą suvaidinti tarptautini vaidmenį laikotarpiu po plètros. Tačiau, antra vertus, tai gali rodyti ir norminị bei etini supratimą pareigos, kurią šios valstybès jaučia turinčios atlikti padėdamos tiems, kuriems ne taip pasisekè. Šis aspektas akivaizdus Lietuvos užsienio reikalų ministro Antano Valionio 2004 m. sausio mèn. padarytame pareiškime:

Naryste ES ir NATO skatins mus skleisti savo demokratijos patirtị. Dirbsime, kad būtume tikri, jog demokratijos sèklos išleis tvirtas šaknis ị rytus nuo mūsų. Pasiūlysime savo pagalbą toms šalims, kurios stengiasi perimti demokratijos ir laisvès vertybes, kad galètų vykdyti savo vidines reformas, ir stengsimès skatinti jų integraciją i Vakarų struktūras. Kalbant apie išorines problemas, Lietuva gali geriausiai pasitarnauti platesniam saugumui ir toliau išlaikydama regioninio bendradarbiavimo lyderio vaidmenį, dalindamasi savo patirtimi, kuriant demokratiją ir laisvosios rinkos ekonomiką su tomis šalimis, kurios lieka už ES ir NATO plètros rajono ribų. ${ }^{33}$

Panašias mintis pakartojo ir buvęs Estijos užsienio reikalų ministras Toomas Hendrikas Ilvesas, pareiškęs, kad Baltijos valstybès turi ypatingą patyrimą, kurị igijo padėdamos buvusioms komunistinėms šalims pereinamuoju metu. Dar daugiau -jos ne tik turi patyrimo, tačiau, anot jo, pačios išgyvenusios ši procesą ir siūlydamos patarimus bei pagalbą, yra daug labiau patikimos nei tokios valstybès kaip Prancūzija, Vokietija, Jungtinè Karalystè ir, žinoma, Šiaurès šalys ${ }^{34}$.

${ }^{33}$ Cituojama Miniotaitès pranešime, (31 išnaša).

${ }^{34}$ Ilves T. H., ,The Grand Enlargement and the Great Wall of Europe” in Kasekamp A., ed., The Estonian Foreign Policy Yearbook 2003, Tallinn: The Estonian Foreign policy Institute, 2003 p. 197. 
Tokios kalbos paremtos ir praktika. Pavyzdžiui, Baltijos valstybės ir Lenkija pradejjo telkti pastangas, siekdamos padèti savo artimoms kaimynėms Baltarusijai, Moldovai ir Ukrainai, ypač demokratijos skatinimo, teisės normu įtvirtinimo bei pilietinès visuomenès stiprinimo srityse. Čia galima būtų paminèti žurnalistams ir parlamentarams organizuotus seminarus ${ }^{3}$. Panašiu būdu Lenkija taip pat siekè atlikti pagrindinị vaidmeni formuojant ES politiką šių šalių atžvilgiu, pasiūlydama Rytų dimensiją ${ }^{36}$. Vis labiau stiprinami užmezgami ryšiai ir su trimis Užkaukazès valstybėmis - Armėnija, Azerbaidžanu ir Gruzija. Pavyzdžiui, Lietuva yra pasiūliusi dabar vykstantị dialogą tarp Baltijos valstybiụ ir trijų Užkaukazès respublikų, kur Lietuva yra lyg tiltas tarp šių šalių bei ES ir NATO ${ }^{37}$. Analogija, prisiminus Šiaurès ir Baltijos valstybių santykius 1990-aisiais, atrodo, akivaizdi. Panašu ir tai, kad Baltijos valstybès pradejjo teikti pagalbą gynybos srityje reorganizuojant šių valstybių kariuomenes pagal NATO standartus ir prisideda prie jų rengimo padengdamos karininkų, studijuojančių Baltijos gynybos koledže Estijoje, mokymo išlaidas ${ }^{38}$.

Reikètų paminèti ir tai, kad nors idealizmas, kuriuo rèmèsi dauguma Šiaurès valstybių veiklos Baltijos jūros regione 1990-aisiais projektų, mažeja, tačiau jis anaiptol neišnyko, o dabar yra telkiamas kitur - ten, kur, manoma, reikès pagalbos raidai užtikrinti, - Baltarusijoje, Moldovoje, Ukrainoje ir Užkaukazės respublikose ${ }^{39}$. Kitaip sakant, atrodo, kad Baltijos jūros regionui perejus iš stabilizacijos ịnormalizacijos laikotarpị, Baltijos jūros šalių idealizmas išplito ị kitą regioną rytuose, kur reikalinga stabilizacija. Tačiau lieka neaišku, ar, nesant vieningų istorinių bendrumų, tokių, kokie, sakysim, buvo Hanzos Sajungoje, šių šalių solidarumas bus tokio pat lygio ir toks pat tvirtas kaip Šiaurès ir Baltijos valstybių.

Tačiau apskritai Šiaurès šalių internacionalizmo suvokimas dabar yra plačiai priimamas ir visame Baltijos jūros regione, o visos Baltijos ir Siaurès valstybės reorganizuoja savo karines struktūras taip, kad jos galètų atlikti vadovaujamą vaidmenị tarptautinèse taikos palaikymo ir ịvedimo operacijose. Iš tiesų tuo metu, kai idealizuotas bendradarbiavimo Baltijos jūros regiono viduje supratimas kelia vis daugiau abejonių, reikia pažymèti, jog bendradarbiavimas, susijęs su išoriniais humanitarinès pagalbos ir taikos palaikymo klausimais, plètojasi labai sèkmingai. Taigi, atrodo, nepaisant to, jog Baltijos jūros regiono viduje gal ir trūksta aiškaus savitumo ir identiteto suvokimo, vienas dalykas, kuriuo pasižymėjo regioninis bendradarbiavimas 1990-aisiais, buvo tai, kad jis dave pagrindą atsirasti iš dalies idealizuotam regioniniam požiūriui ị tarptautinius reikalus, pagrịstus internacionalizmo ir solidarumo idealais.

\footnotetext{
${ }^{35}$ Carlsen P., „From the Baltic States to the Caucasus: Regional Cooperation after the Enlargements“, Lithuanian Foreign Policy Review 1 (9), 2001, p. 28.

${ }^{36}$ Lenkijos Respublikos užsienio reikalų ministerija, 2003. 'Non-paper with polish proposals concerning policy towards new Eastern neighbours after UE enlargement', Warsaw: 2003 m. sausio mèn. Žr. http://www.msz.gov.pl.

${ }^{37}$ Miniotaitè, (31 išnaša)

${ }^{38}$ Ibidem.

${ }^{39}$ Stålvant, (4 išnaša). Pvz., 2004 m. gegužès mėn. Suomijos gynybos ministerija kartu su NATO gynybos koledžu finansavo keturiu dienu seminara Suomijoje „Pietu Kaukazas - vertybiu skatinimas per bendradarbiavimą“, žr.: http://www.defmin.fi. Be to, 2004 m. birželio mèn. Švedija pareiškè, kad padidins plètros paramą Gruzijai iki 54 mln. Švedijos kronų per metus nuo 2004 m. iki 2006 m., Užsienio reikalų ministerijos pranešimas spaudai, $2004 \mathrm{~m}$. birželio $16 \mathrm{~d}$., žr.:http://www.sweden.gov.se/sb/d/4001/a/25810 . Liepos mèn. ji taip pat pranešè, kad padidins finansavima rengiant Rusijos, Ukrainos, Baltarusijos ir Moldovos ekonomistus. Žr.: ,Sweden to contribute SEK 10 million towards edition of economists in Ukraine and Russia', $2004 \mathrm{~m}$. liepos $2 \mathrm{~d}$. http://www.sweden.gov.se/sb/d/4166/a/27093.
} 